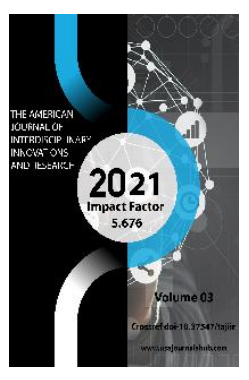

\title{
The Tradition Of Khamsanavism In The Timurid Period
}

Dilrabo Khidirboevna Nazarova

Independent Researcher, Department of "History of Classical Literature", Samarkand State University, Uzbekistan

Copyright: Original content from this work may be used under the terms of the creative commons attributes 4.0 licence.

\section{ABSTRACT}

The article provides information about the tradition of Khamsanism in the Timurid period and its place in the literature of the period, as well as which artists wrote in response to which epics of Khamsatai. Also, according to his contribution to the Khamsanavis, the Khamsanavis poets are conditionally divided into groups and information about them is given.

\section{KEYWORDS}

Khamsa, tradition of khamsanavis, originality in khamsanavis.

\section{INTRODUCTION}

In the time of the Timurids, when we talked about hamsanavism, first of all, we found it possible to give a brief information about hamsa. The word "Khamsa" is derived from the Arabic word "hams" meaning "five", and in literary criticism, a work consisting of 5 epics 
that are close in content and ideology is called hamsa. Hamsanavism begins with the PersianTajik poet Nizami Ganjavi of the XI-XII centuries

\section{THE MAIN FINDINGS AND RESULTS}

The tradition of responding to Nizami Ganjavi's epics became a tradition after the creation of Amir Khusraw Dehlavi's Hamsa. As a result, many poets have made it a criterion to show their poetic potential by responding to Hamsatayn. Although this tradition continues to the present day, it reached its peak during the reign of the Timurids. Azerbaijani scholar Ghazanfar Aliyev, while studying manuscripts and sources in world libraries, identified about 300 authors in response to Nizami Ganjavi's epics and briefly described them in the monograph "Temi i syujeti Nizami v literaturax narodov Vostoka - Themes and plots of Nizami in the literature of the peoples of the East".

When reviewing this monograph, it became clear that the literary environment of the 15th century Herat plays an important role in the history of Hamsanavism. In this environment, led by Jami and Navoi, about 20 artists tried their hand at writing. Although not all of these writers wrote a complete answer to Hamsatayn, they did express their attitude to this tradition by writing a response to this or that epic of the five. Alisher Navoi's "Majlis unnafois", Davlatshah Samarkandi's "Tazkirat ush-shuaro", Zahiriddin Muhammad Babur's "Boburnoma", Muhammad Haydar Doglot's "Tarihi Rashidi", Humoyiddin Khandamir's "Makorim ul-akhloq" and others addressed the Nizami themes of this period. "Habib us-Siyar" also contains information.
The authors of the textbook "Navoi Studies" Sh.Sirojiddinov, D. Yusupova, O. Davlatov, conditionally divided the poets who lived and worked in this period into three groups, based on their contribution to the study of poetry:

1) The authors of the full "Khamsa".

2) Artists who wrote answers to some of Hamsa's epics.

3) Artists who wrote a response to a friend [1, pp. 54-101].

According to Ghazanfar Aliyev, the first poet to create a complete "Khamsa" during this period was a poet with the pseudonym Jamoli, who lived during the reign of Amir Temur and Shahrukh Mirzo. No other information about his life and activities has survived. Jamali's "Khamsa" consists of the following epics:

1. "Tuhfat ul-Abrar" ("Gift of good people", answer to "Mahzan ul-asror").

2. "Mehr-u Nigor" (answer to the epic "Khusrav and Shirin").

3. "Mahzun and Mahbub" (look at the epic “Layli and Majnun”).

4. "Haft avrang" ("Seven thrones", "Seven thrones").

The name of the fifth epic is not clear. However, since the content of the events and the weight used are reminiscent of Nizami's Iskandarnoma, it can be considered as a response to the last epic in the Nizami Five.

We have not been able to capture these epics. Only the naming of the epics suggests that the five were known to Jami and Navoi. In particular, the fact that Jamali's first epic is called "Tuhfat ul-Abror" is reminiscent of the first epics of Jami ("Tuhfat ul-Ahror") and Navoi ("Hayrat ul-Abror"). Also, the fact that 
the title of the epic written in response to "Haft Paykar" is the same as the new series founded by Jami - "Haft Avrang" brings this hypothesis closer to reality.

It is known that Ashraf Maraghi, who wrote a complete answer to the Khamsa epics, lived in the time of Shahrukh Mirzo and died in 1450. His five epics were written between 1428 and 1444 and consist of the following epics:

1. "Minhoj ul-Abror" (The Way of the Good People, 1428). This didactic epic is slightly different from Nizami's epic in this direction and consists of 21 articles (20 articles and 20 stories in Nizami) and two stories are attached to each of them.

2. "Riyaz ul-Ashiqin" (The Garden of Lovers, 1432). In some sources it is indicated as "Khusrav and Shirin".

3. "Ishqnoma" (Tatabbu to "Layli and Majnun", 1438)

4. "Haft Avrang" ("Seven thrones", "Seven thrones", 1440)

5. "Zafarnoma" (1444). Despite the uniqueness of the name, both the description of the events and the weight used are reminiscent of Iskandarnoma.

In our opinion, there are some inaccuracies in the writing history of Ashraf Maraghi's epics. According to Majlis un-nafois, Navoi saw Mawlana Ashraf and talked to him. He describes in detail the way he dressed and how he looked, as well as the fact that he spent most of his life writing "Khamsa". The famous Russian orientalist E.E. Bertels notes that "only the Haft Avrang Masnavi came from Ashraf's epics" (p. 27). In 1998, the Azerbaijani scholar Tohir Ahmad oglu Muharramov published a critical text of the poet's two epics - "Minhoj ul-Abror" and "Riyaz ul-Ashiqin".

The common feature of Jamali's and Ashraf Marogi's "Khamsa" is that there is a possible retreat from the traditional images in the epics of Nizami and Amir Khusrav. For example, Jamali introduces new characters named "Mehr and Nigor" in his epic poem "Khusrav and Shirin". In response to the epics of "Layli and Majnun", which were based on Arabic love, he created the images of "Mahzun and Mahbub". Ashraf names his epics differently: Under the names "Riyaz ul-Ashiqin" and "Ishqnoma" he tries to create new images, new interpretations. This is the basis for its assessment as a new aspect of the Timurid period.

We will not dwell on the other two artists in this group, Alisher Navoi and Abdurahmon Jami, as we will discuss them in more detail at the end of the topic.

Abdullah Hotifi is one of the authors of some of Khamsa's epics. Hatifi lived between 1445 / 501521. In the sources, Abdurahman is mentioned as Jami's nephew. His following epics are known:

1. "Layli and Majnun".

2. "Shirin and Khusrav" (1490).

3. "Haft Manzar" (created as a taboo for "Seven landscapes", "Seven landscapes").

4. "Temurnoma". This epic, written in the weight of "Iskandarnoma", is dedicated to the victorious march of Amir Temur. The epic is 4,500 bytes long and was published lithographically in 1869 in Lakhnav.

Among the Khatifi epics, there is not only an epic written in response to "Mahzan ul-Asror". 
Instead, he decided to create a "Shohnama" (also known in the sources as "Ismailnama", "Shohnomai Hotifi", "Futuhoti khaniy"), dedicated to the activities of Shah Ismail Safavi. This epic, which began to be written on the instructions of Ismail Safavi, is about to end. The manuscripts of the epic, which is about a thousand bytes long, are kept in the Manuscripts Fund of the Abu Rayhan Institute of Oriental Studies, the National Library of the Islamic Republic of Iran, the Saltikov-Shedrin Library in Russia and the Rogibpasha Library in Turkey. Tajik scholar S. Asadullaev published a critical text of the epics "Layli and Majnun" and "Shirin and Khusrav" in Moscow. "Shirin and Khusrav" and Haft Manzar were published in Dushanbe under the editorship of Jobulko Dodalishoev. The unfinished Shahnameh Hotifi was published in the Islamic Republic of Iran by Saidali Ali Dawud.

Kotibi Turshezi is another poet who wrote in response to some of Khamsa's epics and left a certain mark on Hamsa. E.E. Bertels, in his study Navoi i Jami, states that this artist came from Nishapur and died in Astrobod in 1434/36. According to Bertels, the Secretary is the author of about 10 Masnavi-epics, only three of which are based on the Hamsa epics:

1. "Gulshani abror" ("Gulshani of good people").

2. "Layli and Majnun".

3. "Bahrom and Gulandom".

According to the Tajik literary critic Alokhan Afsahzod, the secretary did not write the epic "Layli and Majnun": At the end of his life, the secretary intended to write "Khamsa". However, he managed to write the epic "Gulshani abror" only in response to Nizami's epic “Makhzan ul-asror". Death did not allow the Secretary to respond to other Hamsa epics. In other words, the secretary never wrote a poem called "Layli and Majnun". According to Afsahzod, such a strange idea was formed due to the fact that in the catalog of the St. Petersburg Public Library named after B. Dorn Nizami Ganjavi's epic "Layli and Majnun" was mistakenly attributed to the Secretary. Therefore, in a number of studies, the Secretary was introduced as the author of the epic "Layli and Majnun".

Zabehullo Safa notes in his History of Iranian Literature that the epic Gulshani Abror was written only in response to Nizami's Hamsa, but does not comment on Bahrom and Gulandom. With this in mind, it will be necessary to consider in future studies whether the Secretary will be among the poets who wrote in response to some of Hamsa's epics.

One of the poets who made a worthy contribution to Hamsanavism was Hilali Astarabodi, a Persian poet of Uzbek origin, one of the youngest students of Alisher Navoi. Hilali was born in the 1970s and quickly came to Navoi's attention with his strong memory and high poetic potential. His complete memorization of "Khamsatain" was emphasized by Navoi and Babur. There are 2 epics written by Ubaydullah, a representative of the Shaybani dynasty, in response to the Hilali "Khamsa" epics executed in 1529:

\section{1. "Sifat ul-ashiqin" (Answer to "Makhzan ul- asror").}

2. "Layli and Majnun". 
There is also Hilali's epic "King and Dervish", but this epic is not among the "Masnavis" in the tradition of "Khamsa".

An artist named Shahobiddin Jami is also a follower of the Khamsa tradition. The years of birth and death of this artist are unknown. According to Khandamir's "Makorim ulakhlaq", Shahobiddin Jami wrote the epics "Layli and Majnun" and "Khusrav and Shirin" on the advice of Alisher Navoi. Based on this information of Khandamir, it becomes clear that the author lived in the second half of the $\mathrm{XV}$ century. These two epics of Shahobiddin Jami have not reached us or have not been found yet.

\section{Authors who responded to a friend:}

This group can be divided into two depending on the ideological author:

Authors of the epic “Mahzan ul-Asror”:

Osafi Hiravi, Nargisiy, Ghiyosiddin Sabzavari, Fasih Rumi, Sayyid Qasimi.

Authors of the epic "Layli and Majnun":

Sheikh Suhaili, Ali Ahi, Khoja Imod Lori, Khoja Hasan Hizrshah, Judge of Zova.

It is obvious that the epic with more answers than Nizami's five is his "Makhzan ul-Asror". For, while the subject of this epic is mysticaldidactic, it must be the product of the creative genius of the thinker, his broad outlook, his philosophical-mystical advice. In other words, to write a response to this epic requires not only poetic talent but also the potential for thinking. Creators who specialize in the poetic expression of emotions do not always find enough power in this epic, which is a rare example of contemplative poetry, so the responses to this epic are relatively rare.

\section{CONCLUSION}

It should be noted that in the time of the Timurids, the first epic was created on the basis of the concept of abror in three of the creators of the complete "Khamsa". It is no coincidence that neither Jamali, nor Ashraf, nor Navoi wrote their first epics about the abras. In the Hamsa, the issue of abror is interpreted not in the first epic, "Tuhfat ul-Ahror", but in the epic "Subhat ul-abror", which is the subject of our study. Therefore, it is necessary to get a clearer idea of the subject of abrorism, its history and genesis. We will tell about this in our next articles.

\section{REFERENCES}

1. Sh.Sirojiddinov, D.Yusupova, O.Davlatov. (2018) Navoi Studies. Textbook. Tashkent: Tamaddun. - pp. 54-101.

2. Dehlavi, Amir Khusrav. Matla-ul-Anwar. The critical text of the first Masnavi. With corrections and introduction by Tohir Ahmad-Ugli Muharramov.- Moscow: Donish, 1975. / A. Dehlavi.

3. Nizami Ganjavi, Abu Muhammad llyas. College. Volume 1. Printer and author of the introduction Z.Ahrori / Z.Ahrori - Dushanbe: Irfon, 1981. $-463 \mathrm{p}$.

4. Persian and Tajik literature of the XII-XIV centuries. Part two.- Dushanbe: Donish, 1986.- 232p.

5. Amirkulov, S. Comparison of the stories "Yusuf and Zulaikho" by Haziq and Jomi / Jomi Festival. Collection of articles dedicated to the 550th anniversary of 
Abdurrahmoni Jomi.- Dushanbe: Irfon, 1966. - p. 151. - pp. 98-120.

6. Asadullaev, S. Jomi and Hatifi / Jomi Festival. Collection of articles dedicated to the 550th anniversary of Abdurrahmoni Jomi. - Dushanbe" Irfon, 1966. - p. 151. pp. 36-47.

7. Afshzod, Alokhan. Persian and Tajik literature in the second half of the XV century. / A. Afsahzod. - Dushanbe: Donish, 1987. - p. 264. 